UOT 620.197 .3

\title{
POLARIZATION STUDIES OF STEEL IN THE PRESENCE OF SYNERGETIC MIXTURES BASED ON INORGANIC OXIDIZERS AND MONOETHANOLAMINE IN SODIUM CHLORIDE SOLUTIONS
}

\author{
S.Ch. Verdiev ${ }^{1}$, S.Z. Dzhafarova ${ }^{2,3}$ \\ ${ }^{1}$ Acad. M. Nagiyev Institute of Catalysis and Inorganic Chemistry \\ of the National Academy of Sciences of Azerbaijan \\ H. Javid ave., 113, AZ1143, Baku, Azerbaijan Republic \\ ${ }^{2}$ Azerbaijan State University of Economics (UNEC) \\ Istiglaliyyat ave., 6, AZ1001, Baku, Azerbaijan Republic \\ ${ }^{3}$ Acad. G. Abdullayev Institute of Physics of the National Academy \\ of Sciences of Azerbaijan \\ H. Javid ave., 135, AZ1143, Baku, Azerbaijan Republic \\ e-mail: exiton1992@mail.ru
}

Received 09.03.2021

Accepted 13.04.2021

\begin{abstract}
Polarization studies have shown that the effect of inhibitors containing inorganic oxidants and monoethanolamine reduces the corrosion rate of steel in $3 \% \mathrm{NaCl}$. This decrease unambiguously indicates a simultaneous slowing down of the cathodic reduction of molecular oxygen and the anodic reaction of metal ionization. Based on the studies carried out, it was concluded that the developed mixtures function as mixed -type inhibitors.
\end{abstract}

Keywords: polarization, inhibitor, cathodic and anodic processes, ionization, synergetic effect.

DOI: 10.32737/2221-8688-2021-1-37-40

\section{Introduction}

According to previously obtained data [1-5], it showed that the combined introduction of inorganic oxidizing agents and amines at the certain ratios into a corrosive medium leads to a noticeable decrease in the corrosion rate of carbon steel. In this regard, it is of scientific interest to study corrosion-electrochemical properties of St.3 in these mixtures and find out reasons of braking effect of the used inhibitors.

Previously, we obtained data on the effect of the concentration of inhibitors on electrode potentials under open circuit conditions, since these changes can be used to indirectly judge about possible effect of synergistic mixtures on the course of electrode reactions occurring on the steel surface.

\section{Experimental part}

Electrochemical measurements were carried out on a Pi-50-1 potentiostat with a separated anode and cathode space. As an electrode, a rotating disk electrode $(970 \mathrm{rpm})$ was taken from steel gradest 3 with a working surface of $1 \mathrm{~cm}$. Potentials were measured relative to the silver chloride electrode and recalculated to the normal hydrogen scale. The auxiliary electrode was platinum. Polarization curves were recorded in the potentiodynamic regime with a potential sweep rate of $12 \mathrm{mV}$ per minute. 


\section{Results and discussion}

The removal of polarization curves in the potentiodynamic regime for the tested metal in a given corrosive sphere without additives and in the presence of inhibitors allows us to find out which of the processes (anode or cathode) is mainly braked by the introduction of inhibitors, components and their mixtures.

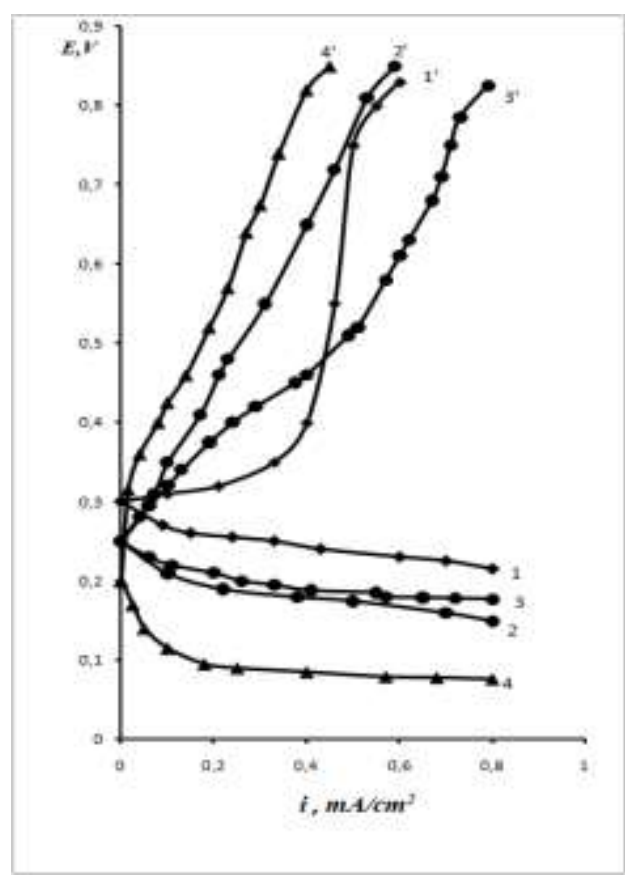

Fig. I. Cathode, anode polarization curves of St. 3 in a $3 \% \mathrm{NaCl}$ solution with the addition of an inhibitor, mg/1: 1-1 '- without inhibitor; 2-2'-NaNO $2-100 ; 3-3$ '-MEA - 100; 4-4'- $\mathrm{NaNO}_{2}-100+$ MEA - 100

In Fig. 1 polarization curves taken in a 3\% $\mathrm{NaCl}$ solution and in the presence of monoethanolamine (MEA) are presented, $\mathrm{NaNO}_{2}$ individually and in their mixture. As can be seen from Fig. 1, with the addition of $\mathrm{NaNO}_{2}$ $(100 \mathrm{mg} / 1)$ in the background solution (3\% solution of $\mathrm{NaCl}$ ), the electrode potential is shifted to a positive direction at $80 \mathrm{mV}$. At the same time, both cathodic and anodic processes are simultaneously braked, and the inhibition of the latter is stronger. With the addition of monoethanolamine $(100 \mathrm{mg} / \mathrm{g})$ to the background solution, the cathodic process is mainly inhibited. The addition of both $\mathrm{NaNO}_{2}$ and monoethanolamine $(100 \mathrm{mg} / \mathrm{g})$ to the solution simultaneously leads to stronger suppression of both cathodic and anodic processes (Fig. 1. curves 4-4'.)

As follows from Fig.1, both individually and jointly, $\mathrm{NaNO}_{2}$ and MEA are able to change the kinetics of electrochemical processes on steel and lead to a noticeable decrease in the corrosion rate. The greatest effect is observed in the mixture of these inhibitors. In this work, along with the above mentioned inhibitor, we studied other mixtures of inhibitors as well, in particular, mixtures of potassium chromate and MEA. Polarization measurements showed that the combined presence of two components in the mixture $\left(\mathrm{K}_{2} \mathrm{CrO}_{4}+\mathrm{MEA}\right)$ leads to a noticeable braking of cathodic and anodic processes. Moreover, the inhibition of the anode process in this case is greater than in the presence of sodium nitrate (Fig. 2). A study into kinetics of the anodic ionization reaction of steel in the presence of a mixture of MEA with sodium molybdate revealed that although monoethanolamine and sodium molybdate contribute to some anodic polarization of the electrode, their mixture with a synergistic property, has the greatest influence on this process. 
In our opinion, the mechanism of the protective effect of MRA mixture and $\mathrm{NaNO}_{2}$ is that a chemisorbed layer of iron hydroxide which includes monoethanolamine is formed on the outer protective layer of iron oxide, and in the case of chromate with MEA, a complicated complex of chromium with iron of the chelated type is formed on the steel surface.

Thus, there is a definite correlation of the influence of studied inhibitors on the corrosion rate and the anodic reaction of steel ionization.

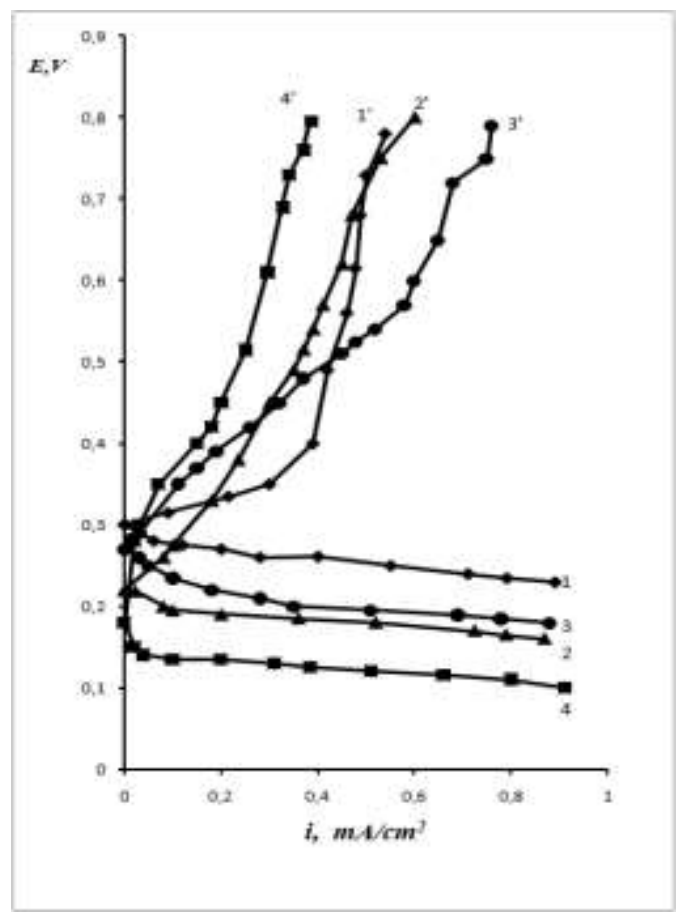

Fig. 2. Cathode and anode polarization curves of St. 3 in a $3 \% \mathrm{NaCl}$ solution with the addition of an inhibitor, mg/1: 1-1'- without inhibitor; 2-2'- $\mathrm{K}_{2} \mathrm{CrO}_{4} 10$; 3-3'- $\mathrm{H}_{2} \mathrm{~N}-\mathrm{CH}_{2}-\mathrm{CH}_{2}-\mathrm{OH}-90$; 4-

$$
4^{\prime}-\mathrm{K}_{2} \mathrm{CrO}_{4}-\mathrm{l} 0+\mathrm{H}_{2} \mathrm{~N}-\mathrm{CH}_{2}-\mathrm{CH}_{2}-\mathrm{OH}-90
$$

\section{Conclusion}

Electrochemical studies show that in neutral electrolytes a synergistic effect of inhibiting the corrosion process is observed, with the combined presence of these oxidizing agents and MEA in a corrosive environment. These mixtures exert a braking effect both on cathodic and anodic processes.

\section{References}

1. Verdiev S.Ch., Kazakhsky L.P., Bayramov A.Kh., Kyazimov A.M. On the nature of the synergism of oxidative inhibitors and monoethanolamine on the surface of steel in a chloridesolution. Metal Protection. 1987. vol. XXIII, no. 2, pp. 264-269. (In Russian).

2. Verdiev Ch., Tagirli H.M., Agalarova T.A., Huseynova A.S., Velieva S.M., Jafarova S.Z., Mamedova S.R. Inhibition of contact corrosion of metals in fresh water with mixtures of oxidizing agents and amines. Chemical Problems. 2019, vol. 3, no.17, pp.
465-469.

3. Rakova T.M., Kozlov A.A., Nefedov N.I., Lapatov A.B. Study of the effect of organic and inorganic corrosior inhibitors on corrosion cracking of high-strength steels. Proceedings of the All-Russian Scientific Research Institute of Aviation Materials (VNAM). 2017. vol. 6, no. 54, pp. 102-110.

4. Grigorieva I.O., Dressvyanikov A.F. The effect of the composition and concentration of nitrate-containing electrolytes on the anodic dissolution and the corrosion behavior 
of aluminum. Bulletin of Kazan Technological University. 2012. no.1, pp. 6972.

5. Verdiev S.Ch., Tagirli H.M., Agalarova T.A., Huseynova A.S., Velieva S.M. Investigation of the effect of the combined inhibitory effect of inorganic oxidants and monoethanolamine on steel corrosion in a two-phase electrolytehydrocarbon medium. Journal «Caspian Corrosion Control». 2019. no.1, pp. 6-10.

\title{
QEYRİ-ÜZVI OKSIDLOSDIRICILORIN VO MONOETANOLAMINN OSASINDA HAZIRLANMIŞ INNHIBITTOR QARIŞIĞININ OLDUĞU NATRIUUM XLORID MOHLULLARINDA POLYARLASMANIN TODQIQQI
}

\author{
S.C. Verdiyev ${ }^{1}$, S.Z. Caforova ${ }^{2,3}$ \\ ${ }^{1}$ AMEA-nın Kataliz və Qeyri-üzvi Kimya institutu, AZ1143, Bakl, H.Cavid pr.113 \\ ${ }^{2}$ Azarbaycan Dövlat Iqqtisad Universiteti, AZ1001, Bakl, Istiqlaliyyat pr.,6 \\ ${ }^{3}$ AMEA-nın Fizika İnstitutu, AZ1143, Bakl, H.Cavid pr.135 \\ e-mail: exiton_1992@mail.ru
}

Polyarlaşma tadqiqatları naticasində malum olmuşdur ki, tarkibində qeyri-üzvi oksidlaşdiricilar və monoetanolaminin olduğu inhibitorlar poladın korroziya süratini azaldır ki, bu da birqiymatli molekulyar oksigenin reduksiyası va anod reaksiyası olan metalın ionlaşma proseslarinin langimasina dalalat edir. Hor iki prosesin langimasi hazırlanmış inhibitor sistemlarin qarışıq tipli olduqlarını tasdiq edir.

Açar sözlor: polyarlaşma, inhibitor, katod va anod proseslari, ionlaşma, sinergetik effekt

\section{ПОЛЯРИЗАЦИОННЫЕ ИССЛЕДОВАНИЯ СТАЛИ В ПРИСУТСТВИИ СИНЕРГЕТИЧЕСКИХ СМЕСЕЙ НА ОСНОВЕ НЕОРГАНИЧЕСКИХ ОКИСЛИТЕЛЕЙ И МОНОЭТАНОЛАМИНА В РАСТВОРАХ ХЛОРИСТОГО НАТРИЯ}

\author{
С.Ч. Вердиев ${ }^{1}$, С.З. Джафарова ${ }^{2,3}$ \\ ${ }^{1}$ Институт Катализа и Неорганической Химии АН Азербайджана \\ AZ 1143, Баку, пр. Г. Дюавида,113 \\ ${ }^{2}$ Азербайджанский Государственный Экономический Университет \\ AZ 1001, Баку, пр. Истиглалият, 6 \\ ${ }^{3}$ Институт Физики Национальной АН Азербайджана \\ AZ 1143, Баку, пр. Г. Джавида, 135 \\ e-mail: exiton_1992@mail.ru
}

Поляризачионные исследования показали, что влияние ингибиторов, содержащие неорганические окислители и моноэтаноламин, уменьшают скорость коррозии стали в 3\%-м растворе $\mathrm{NaCl}$. Это уменьшение однозначно свидетельствует об одновременном замедлении катодного проиесса восстановления молекулярного кислорода и анодной реакиии ионизации металла. На основе проведенных исследований сделано заключение о том, что разработанные смеси функиионируют как ингибиторы смешанного типа.

Ключевые слова: поляризачия, ингибитор, катодные и анодные процессы, ионизачия, синергетический эффект. 